\title{
三方位からの透過形電子顕微鏡観察と構造因子計算による $\mathrm{BiFeO}_{3}$ エピタキシャル薄膜の結晶対称性の決定
}

$$
\text { ニューヨーク州立大学ビン八ムトン 裴 黃䆓 }
$$

東北大学工学研究科応用物理学科, フランス国立科学研究センター／タレス, パリ南大学 永沼 博

In-Tae BAE and Hiroshi NAGANUMA: Determination of Crystal Symmetry in Epitaxial $\mathrm{BiFeO}_{3}$ Films using Transmission Electron Microscopy and Structural Calculation by Three Different Directions

Despite extensive studies on crystal structure of thin film $\mathrm{BiFeO}_{3}(\mathrm{BFO})$ thin film, it remains debated primarily due to its structural complexity as well as stress effect from underlying substrates. We have examined comprehensive crystal structure analysis for BFO thin layer $(30 \mathrm{~nm})$ grown on $\mathrm{SrTiO}_{3}$ ( $\mathrm{STO}$ ) substrate using cross-sectional transmission electron microscopy technique along three different zone axes. Nano-beam electron diffraction (NBED) patterns combined with structure factor (SF) calculations and high-resolution transmission electron microscopy images unambiguously reveal that BFO thin layer grows with rhombohedral structure that is identical to its bulk form. No evidence of monoclinic and/or tetragonal distortion is found. The rhombohedral BFO thin layer is found to grow onto STO by maintaining an epitaxial relationship in a manner that can minimize lattice mismatch at BFO/STO interface. Our current work clearly demonstrates that multiple-zone axes NBED combined with SF calculation is highly effective for precise crystal structure analysis of thin film BFO.

\section{1. はじめに}

$\mathrm{BiFeO}_{3}(\mathrm{BFO})$ は強誘電性および反強磁性の秩序を兼 備したマルチフェロイックスの1つである.1 ${ }^{1,2)} \mathrm{BFO}$ の強 誘電性転移温度およびNéel温度は室温以上にあり, さら に電気磁気結合が室温以上で観測されてから, 多值メモ リ，低消費電力の電界駆動型不揮発性磁気メモリおよび 超高感度磁気センサなどのスピントロニクスデバイス への利用が期待されている. BFOの強誘電性に着目する と, 最初の測定は菱面体晶構造のバルク $\mathrm{BFO}$ で行われ, そのときの自発分極值は $3.5 \mu \mathrm{C} / \mathrm{cm}^{2}$ であった.3) その後, (100) $\mathrm{SrTiO}_{3}(\mathrm{STO})$ 基板上にエピタキシャル成長させた 高品質 $\mathrm{BFO}$ 薄膜において $60 \mu \mathrm{C} / \mathrm{cm}^{2}$ の高い自発分極が室 温で報告された.4) 第一原理計算によると, 正方晶 $\mathrm{BFO}$ の 自発分極值は $150 \mu \mathrm{C} / \mathrm{cm}^{2}$, 菱面体晶 $\mathrm{BFO}$ は $100 \mu \mathrm{C} / \mathrm{cm}^{2}$ となることが報告5)されており, BFOの結晶対称性が自 発分極に大きく影響することがわかる。強誘電体トンネ ル接合デバイス 6) などでは高い自発分極を有する正方晶 構造のBFOをトンネル障壁材料として用いることが望 ましい.7)電気磁気効果に着目すると, 結晶の対称性から 菱面体晶BFO では電気磁気効果は得られるが正方晶構 造では現れない，菱面体晶構造のBFO と強磁性層が界 面を形成すると反強磁性交換結合が生じるため, BFO/ 強磁性二層膜ではBFOの反強磁性面の反転に伴い強磁
性層の磁化が変調もしくは反転することが報告されて いる. ${ }^{8)}$ 最近では $\mathrm{CoFe}_{2} \mathrm{O}_{4}$ のような結晶磁気異方性の高 い $\left(K_{1}=3 \times 10^{6} \mathrm{erg} / \mathrm{cm}^{3}\right)$ 材料でも室温で磁化反転が観 測されており, 電界により磁化を書き換えデバイスへの 応用が期待されている.9)このようにBFOはデバイスの 目的用途により結晶構造を制御する必要があることが わかる。これまでに, BFOエピタキシャル薄膜では基板 との格子ミスフィットにより導入された応力, もしくは 製膜条件・方法などのわずかな影響により，単斜晶歪み を有するCube-on-Cube ${ }^{10)}$ および単斜晶歪みを有する菱 面体晶 11) ドメイン構造を有する単斜晶 12)-14)などさまざ まな結晶構造がX線回折およびX線逆格子空間マッピ ングの解析により報告されてきた. BFOの構造解析には さまざまな方法が挙げられるが, ここでは一般によく使 われているX線回折および電子線回折の 2 つ方法を例 に挙げ, 長所と短所について述べる。通常のX線回折法 を試料に加工する必要がないため簡便に利用できる点 に特徵がある。しかし, エピタキシャル薄膜の場合は試 料が基板と接しているため, 通常のX線回折測定では基 板の回折情報が薄膜試料の回折情報に重畳して, 格子 定数の近いへテロエピタキシャル膜の構造解析を難し くすることがある。したがって, 膜厚を数 $\mathrm{nm}$ まで極薄 化したトンネル障壁の構造解析をX線回折測定で明ら かにすることは困難である。一方, 透過型電子顕微鏡は 
電子を透過させる観察手法であり，試料のナノレベルの 微小領域からの回折情報を得ることができる利点があ る.つまり, 電子を透過させる方向を積層断面とするこ とで数ナノメートルのトンネル障壁層であっても構造解 析を行うことができる。しかし, 試料を加工して数十ナ ノメートルまで薄片化するプロセスが加わるため, 構造 解析のための試料作製の準備に時間を要する.X線回折 は逆空間の局所領域を高精密に測定することが容易な ため, 結晶構造の微妙な歪みに起因した構造の解析を行 うことに適しているが, 全体的な結晶構造を正確に評価 するために必要な逆空間において広い領域の情報 (特に 面内方位) を得ることは容易ではない. X線回折 $(\mathrm{Cu}-\mathrm{K} \alpha$ の場合： $\lambda=0.1540 \mathrm{~nm}$ ) に比べて, $200 \mathrm{kV}$ の高電圧を用 いた透過型電子顕微鏡 $(\mathrm{TEM})$ では電子ビームの波長 $(\lambda$ $=0.00251 \mathrm{~nm})$ が短いことから逆空間において $Q$ (散乱 ベクトル $=220 \mathrm{~nm}^{-1}$ まで広い領域から情報を得ること ができる.15),16) TEMは試料の観察方位を適切に決める ことにより, すべての面内方位に関する逆空間での情報 を得ることができる利点を有する。これまでに, TEMを 用いたBFOの電子線回折測定に関するいくつか報告が あるが, 1つの結晶方位 ([100 $\left.]_{\mathrm{STO}}\right)$ のみ調べており, 包 括的にBFO 薄膜の結晶対称性を議論するためには不十 分であると考えられる、4)，17)，18）これは，TEM観察用の試 料作製に時間を要するため, これまで複数の方位で系統 的に調べられてこなかったことが一因であると考えられ る。以上の背景に踏まえて, 本稿では BFO 薄膜の結晶対 称性を詳細に調べるため, 単結晶 STO上にBFOをエピ タキシャル成長させて 3 つ異なる方位から電子線回折 測定を行い, 構造因子計算との比較検討により包括的な 構造解析を行った. 19 )

\section{2. 実験方法}

$30 \mathrm{~nm}$ 厚さのエピタキシャル BFO 薄膜を (100) STO 基 板上に超高真空r.f. マグネトロンスッパッタリング法に より作製した。製膜前の到達真空度は $2 \times 10^{-6} \mathrm{~Pa}$ 以下 であった。スパッタリングターゲットには 2 インチ径の $\mathrm{Bi}_{0.9} \mathrm{Fe}_{1.0} \mathrm{O}_{\mathrm{x}}$ 焼結ターゲットを用い, 不足する酸素を補う ためアルゴンガスに酸素ガスを混合させたプロセスガ スを用いた. BFOの結晶化のため製膜時の基板温度を $550{ }^{\circ} \mathrm{C}$ とた。 断面観察用の試料作製には機械研磨と $\mathrm{Ar}$ イオンミリング法を用いた. Arイオンミリグのダメー ジを最小限にするため $\mathrm{Ar}$ イオンのエネルギーは $4.0 \mathrm{kV}$ から $1.5 \mathrm{kV}$ まで段階的に低下させながら加工を行った。 断面 TEM 試料の観察には日本電子社製の JEM-2100Fを 用いた，精度の高い結晶構造解析を行うため, STO 基板 を基準として3つの結晶方位からナノビーム電子回折 (NBED) 測定を行った。 なお, 電子線回折に用いた電子 ビームの直径を $10 〜 20 \mathrm{~nm}$ とした. NBEDの精密な検出
のため従来の CCDカメラに比べ電子線ダメージに対し 優れた耐性を有する Gatanの Orius 833 CCD カメラを用 いた.20)

\section{3. 実験結果}

\section{1 r.f. マグネトロンスパッタ法による $\mathrm{BiFeO}_{3}$ エピタ キシャル膜の作製}

酸化物をスパッタリングにより作製するとき, 製膜 時の酸素ガス流量, 投入電力, 基板間距離などの製膜パ ラメーターは膜質および組成比に影響する。ここでは, 組成と表面平坦性に最も影響を与えた酸素ガス流量に ついて述べる. ${ }^{21)}$ 図1は製膜時の酸素ガス流量に対する 図1 $\mathrm{a} \mathrm{Bi}$ と $\mathrm{Fe}$ の組成比および図 $1 \mathrm{~b}$ 結晶構造を示す。酸 素ガス圧を $0.008 〜 0.120 \mathrm{~Pa}$ の間で変化させ, その後に アルゴンガスを加えて酸素ガスとアルゴンガスの全ガス 圧を $0.4 \mathrm{~Pa}$ になるうに調整した。アルゴンガスに対し て酸素ガス流量比は $0 \sim 50 \%$ の間で変化した. 図1aか らアルゴンガスのみで製膜したときは $\mathrm{BiFeO}_{3}$ の化学量 論組成となっていることがわかる。酸素ガスを導入する と, いったん組成がずれ, 酸素ガス流量を増加させると 酸素ガス流量が $7 \mathrm{~cm}^{3} / \mathrm{min}$.のとき $\mathrm{BiFeO}_{3}$ の化学量論組 成となった。さらに酸素ガス流量を増加させると, $\mathrm{Bi}$ と $\mathrm{Fe}$ の組成比が大きくずれていくことがわかった，図 $1 b$
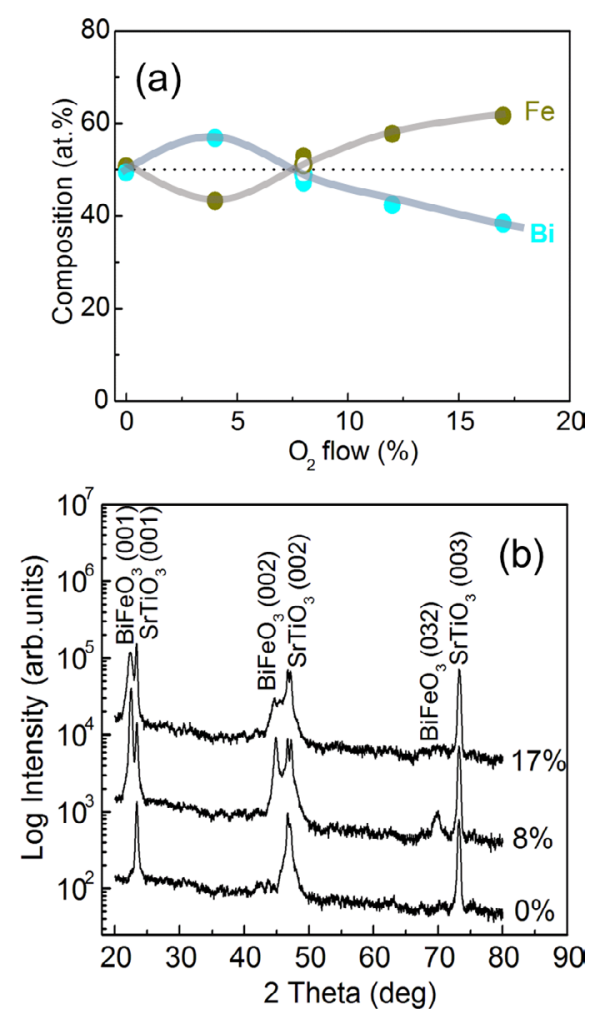

図1(a)スパッ夕製膜時の酸素ガス分圧に対する $\mathrm{Bi}$ と $\mathrm{Fe}$ の組成比, (b) 2 theta-XRDパターン. ${ }^{20)}($ ( a $)$ $\mathrm{Bi}$ and $\mathrm{Fe}$ compositional ratio and (b) 2 theta-XRD patterns as a function of oxygen gas pressure during the sputtering deposition.) 
の X線回折プロファイルからアルゴンガスのみで製膜す ると基板からの回折ピークしか観測されずに, ペロブス カイト相が形成していないことがわかった，酸素ガス流 量比を $7 \%$ 以上とすると $\mathrm{BiFeO}_{3}$ 単相が形成したことがわ かる. しかし，原子間力顕微鏡により表面粗さを観察し たところ, 酸素がス流量比が $17 \%$ \%きは膜表面が粗く

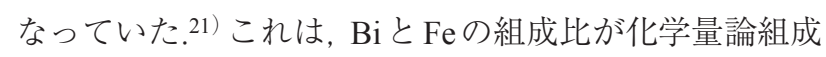
からずれたことによりX線回折では検出できない程度の 異相の微粒子が表面に析出しているためと考えられる. 以上に述べたように結晶構造, 表面平坦性などを考慮す ると, 酸素がス流量比が7\%のとき平坦な表面を有する 単相の $\mathrm{BiFeO}_{3}$ 膜が形成できていることがわかった，以下 の構造解析実験では上記条件により作製した BFO膜を 用いる。

\section{2 [010] STO 方位からの NBED や構造因子計算結果}

図2aは厚さが $30 \mathrm{~nm}$ の BFO薄膜を STO基板の [010] 方位から観察した断面 TEM像である. 図2bはSTO基板 から十分に離れた $\mathrm{BFO}$ 薄膜の白丸の領域から得られた NBEDパターンである. BFO膜の回折スポットから精密 な格子間隔を評価するために, STO基板（立方晶, 空間 群 : $P m \overline{3} m, a=0.3901 \mathrm{~nm}$ ) からの NBEDパターンも同 じ電子線照射条件により測定した（図2d)。な㧍，図2d の白い矢印で示した回折スポットは二重回折によるもの である.22) 図2bと図2dの NBEDパターンから対称性や 回折スポットの位置が類似していることがわかる. STO 基板上に成長させた厚さ $200 \mathrm{~nm}$ の BFOエピタキシャル 膜を用いた構造解析では, NBEDパターンの面直方向 $\left(d_{\text {out-of-plane }}\right)$ と面内方向 $\left(d_{\text {in-plane }}\right)$ のスポットから格子定 数の比を計算し, $d_{\text {out-of-plane }} / d_{\text {in-plane }}=1.016$ であることが 報告されている.10)さらに, この報告ではX線回折実験 を行い, BFOに比べて格子定数が $1.4 \%$ 小さいSTOの影 響により $\mathrm{BFO}$ エピタキシャル膜は面内方向に圧縮され るとともに, $0.5^{\circ}$ の単斜晶傾斜が加えられた正方晶構 造の BFOであると述べている.10) 最近では, 格子定数が $\mathrm{STO}$ に比べて小さく強い圧縮効果が期待できる $\mathrm{LaAlO}_{3}$ （LAO）基板を用いたところ, $\mathrm{LAO}$ 上の $\mathrm{BFO}$ 薄膜は圧 縮応力の影響から面直方向に伸びた巨大正方晶構造の $\mathrm{BFO}$ となることが報告された。年)これは, BFO と LAOの 間にある $4.6 \%$ もの大な面内格子ミスマッチに起因し た圧縮応力によるものと考えられている. 本研究の BFO 試料についても $d_{\text {out-of-plane }}$ と $d_{\text {in-plane }}$ の比を測定すること により格子歪みを評価した（図1b). 図中の白い矢印で 示した2つ回折斑点を用いて精密に測定してみたところ $d_{\text {out-of-plane }} / d_{\text {in-plane }}=1.0$ となり面垂と面内方位の格子歪み はほとんど存在しないことがわかった，図2dに示した 歪みのない $\mathrm{STO}$ 基板からの NBEDパターンを基準とし て図2bのBFOの回折スポットを精密に校正し, これま でに報告されているすべてのBFOの結晶相；菱面体晶
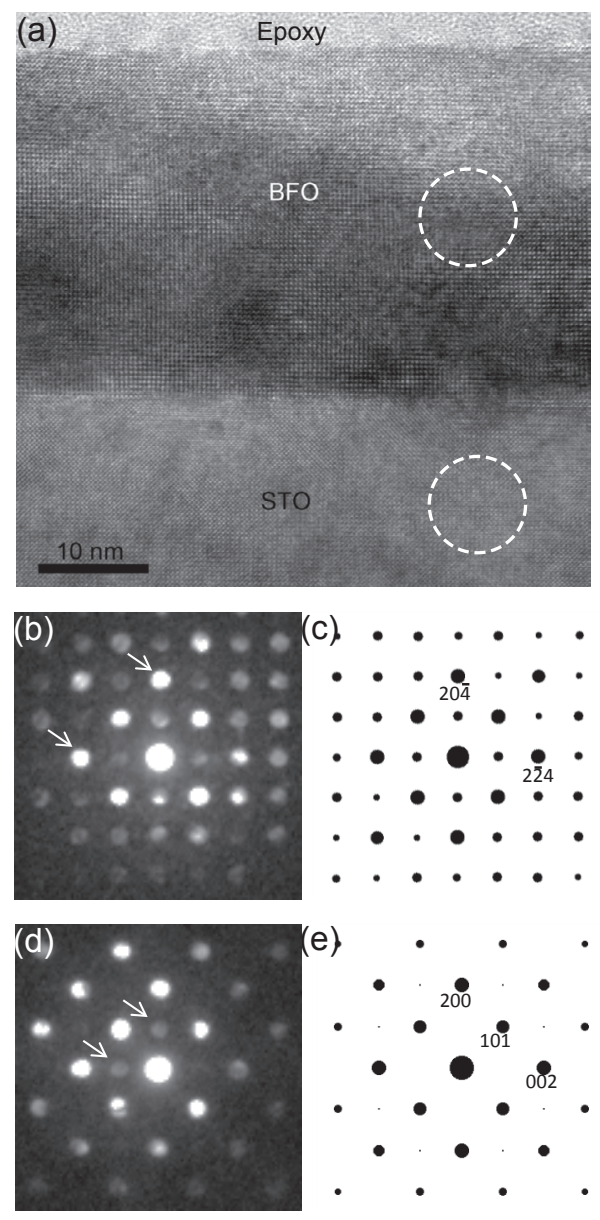

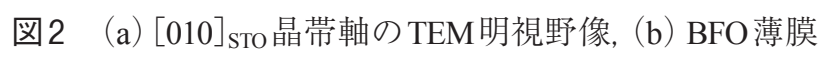
からの NBEDパターン, (d) STO基盤からの NBED パターン. (b) と (d) に相当する構造因子の計算結 果は (c) と (e) である. ${ }^{19)}$ (A cross-sectional BF TEM image of BFO layer from $[010]_{\text {sTo }}$ orientation with NBED patterns from the encircled areas of BFO layer (b) and STO substrate (d). SF calculations of the corresponding NBED patterns are shown in (c) and (e).)

(空間群: $R 3 c, a=0.5678 \mathrm{~nm}, c=1.3982 \mathrm{~nm}$ ), 24) 単斜 晶 (空間群 : $P 2_{1} / m, a=0.5615 \mathrm{~nm}, b=0.7973 \mathrm{~nm}, c=$ $0.5647 \mathrm{~nm}, \alpha=90^{\circ}, \beta=90^{\circ}, \gamma=90.1^{\circ}$ ), ${ }^{25}$ ) 正方晶( 空間 群 : $P 4 \mathrm{~mm}, a=0.367 \mathrm{~nm}, c=0.464 \mathrm{~nm}),{ }^{26)}$ に対して構 造因子 (Fhkl) 計算を行い比較検討した. なお, 構造因子 の計算には kinematical 近似を用いた：

$$
F_{h k l}=\sum_{n} f_{n} \exp \left[2 \pi i\left(h x_{n}+k y_{n}+l z_{n}\right)\right]
$$

ここで, $h k l$ は特定の Bragg 反射, $f_{n}$ は単位胞の中の $\left(x_{n}, y_{n}, z_{n}\right)$ に存在する $n$ 番目の原子の原子散乱因子で ある. 構造因子計算に際しては上述したすべてのBFO 結晶相にて, 図 2b と同等なNBEDパターンが現れる可 能性のあるすべての晶帯軸に対して行った，その結果， 図2Cに示すように菱面体BFOの [241］の回折パターン が図2cと一致することが判明した. 図2cに示す面直と 面内方位に相当する $(20 \overline{4})$ と $(2 \overline{2} 4)$ の面間隔の計算結 
果はいずれも $0.200 \mathrm{~nm}$ となり, 図2bの $d_{\text {out-of-plane }} / d_{\text {in-plane }}$

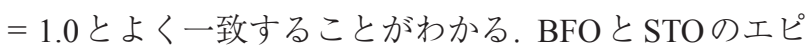
タキシャル関係を調べるために, STO基板の $[010]_{\mathrm{STO}}$ の NBEDパターンも計算した（図2e)。その結果, BFOが $\mathrm{STO}$ 上に菱面体晶の結晶対称性を伴って成長する際, $\mathrm{BFO}$ と STOの面直と面内方向の格子ミスフィットを最 小限に抑える $(<2.5 \%)$ ために, 以下のようなエピタキ シャル関係を保つこと考えられる。

[241] of $\mathrm{BFO} / /[010]$ of STO ;

$(20 \overline{4})$ of $\mathrm{BFO} / /(200)$ of STO

しかし, 図2bと図2dのパターンではその対称性や回折 スポットの距離などがきわめて類似しており，TEMの軸 調整などに十分に注意をしないと回折パターンを擬立方 晶などと見誤る可能性が十分にある。つまり, 相同定の 誤認を避けるためにはほかの方位についても検討して基 板と回折パターンが明瞭に異なる方位を見つける必要 がある。

\section{$3.3[011]_{\text {STO }}$ 方位からの NBED や構造因子計算結果}

NBEDパターンは三次元逆格子空間の二次元的な断 片であることから, 異なる結晶方位からの NBEDパター ンを測定して $[010]_{\mathrm{STO}}$ から得られたエピタキシャル関 係の妥当性を確認する必要がある。図3aは $[011]_{\mathrm{STO}}$ 晶 带軸から観察した断面TEM像である。図3bおよび図2d はBFOとSTOからのNBEDパターンである。先に述べ たように図 $2 \mathrm{~b}$ と図2dのパターンではその対称性や回折 スポットの距離などがきわめて類似していたことに対し て, 図3bと図3dではNBEDパターンの対称性が明らか に異なるため, 基板の NBEDパターンと重複して誤認す ることがほとんどない. 図3bと図3dのNBEDパターン から精密な構造解析を行うために構造因子計算を行っ た結果, 図3bは図3cで示したように菱面体晶のBFOの [211］の回折パターンと一致することが明らかとなっ た. STO [011] の構造因子計算結果は図3eに示してい る。図3bと図3dにて白い矢印で示した回折スポットは 2 重回折に起因する. ${ }^{18)} こ の$ 計算結果から以下のエピタ キシャル関係が得られた：

[211] of $\mathrm{BFO} / /[011]$ of STO ;

$(10 \overline{2})$ of $\mathrm{BFO} / /(200)$ of STO

$\mathrm{BFO}$ と STOの格子ミスフィットを面垂直と面内にてそ れぞれ計算すると， $2.5 \%$ と $2.2 \%$ であることがわかった. この格子ミスフィットの值は上述した $[010]_{\mathrm{STO}}$ から計 算した值とほぼ同じであり，[011 $]_{\mathrm{STO}}$ 方位からの電子線 回折実験においてもBFOとSTOの界面でのミスフィッ 卜は最小限に抑えられていることがわかった（1）と（2） のエピタキシャル関係から, $[010]_{\mathrm{STO}}$ と $[011]_{\mathrm{STO}}$ と対応 した $[241]_{\mathrm{BFO}}$ と $[211]_{\mathrm{BFO}}$ の角度は $45^{\circ}$ となっている必 日本結晶学会誌 第 58 巻 第 2 号 (2016)
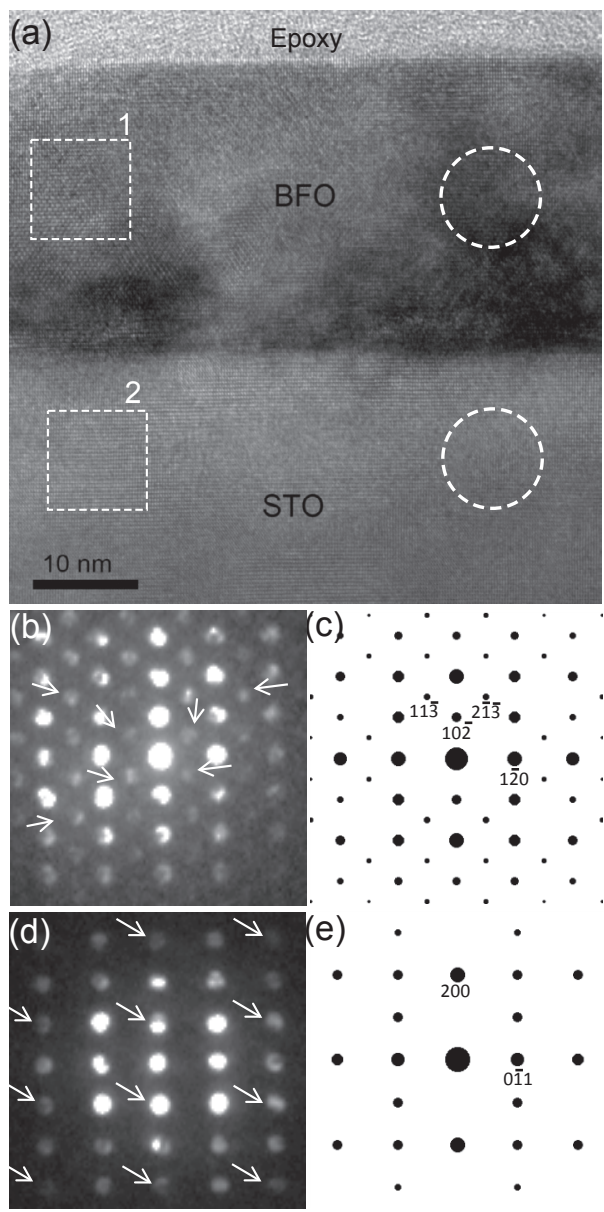

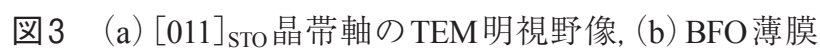
からの NBEDパターン, (d) STO基盤からの NBED パターン. (b) と（d) に相当する構造因子の計算結 果は (c)と (e)である. ${ }^{19)}$ (A cross-sectional BF TEM image of BFO layer from $[011]_{\text {STO }}$ orientation with NBED patterns from the encircled areas of BFO layer (b) and STO substrate (d). SF calculations of the corresponding NBED patterns are shown in (c) and (e).)

要がある、実際に計算すると，[241 $]_{\mathrm{BFO}}$ と $[211]_{\mathrm{BFO}}$ の角 度は $45.0^{\circ}$ となっており, 独自に計算したエピタキシャ ル方位には妥当性があることが証明された。

\section{4 [011] sto方位からの高分解能像とファストフーリ} 工変換 (FFT)

図4は図3aの 1 および2の四角の領域の高分解能 TEM 像とそのFFTパターンである.TEM観察のため図4aと 図4bにて原子構造の違いは区別しにくいが図4bの FFT

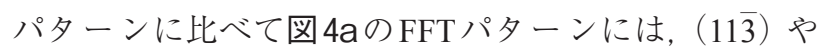
$(2 \overline{1} \overline{3})$ など, 図3bのNBED パターンで得られた菱面体 晶に特有の回折スポットの存在が確認できる. 以上の結 果は, 図3bで示した菱面体晶構造に特有の回折スポッ トはCCDカメラからの虚像や高次ラウエゾーンに起因 するものではなく, $\mathrm{BFO}$ の構造に由来するものである ことを意味している. [011 $]_{\mathrm{STO}}$ 方位からの NBEDパター ンおよび高分解能 TEM像のFFTパターンの両方から菱 

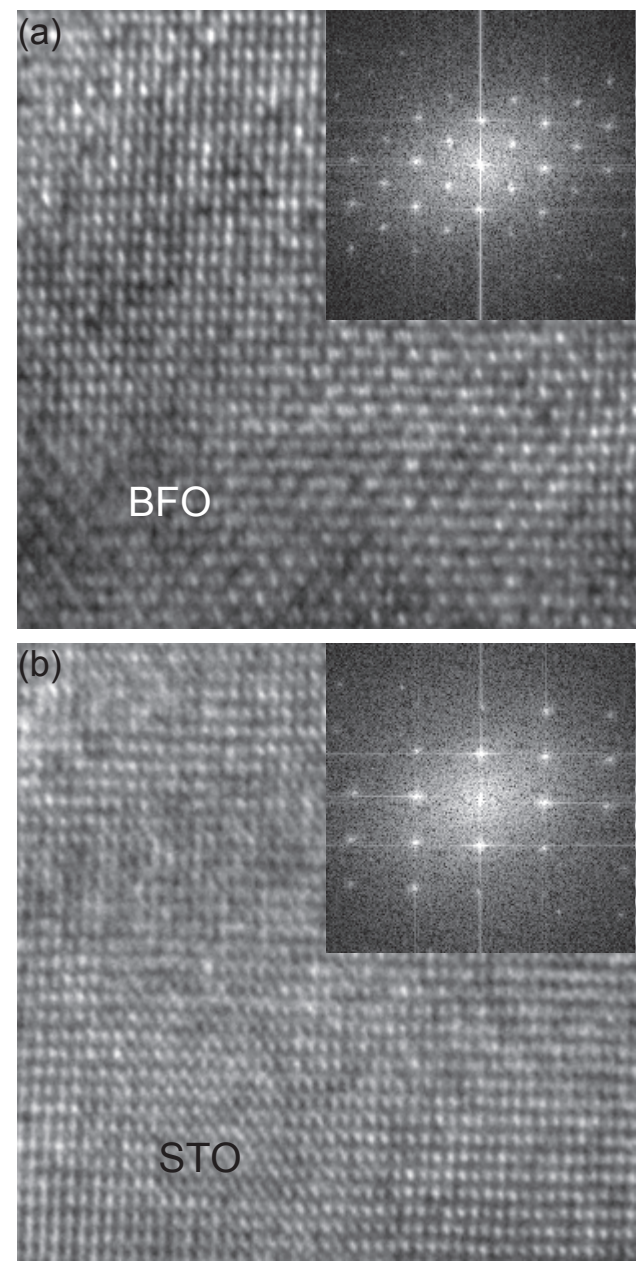

図4（a）図2aにて BFO 薄膜の白い四角形1の部分か らの高分解能像とそのFFTパターン, (b) 図2aに て STO 基盤の白い四角形2の部分からの高分解 能像とそのFFTパターン.19)（(a) HRTEM image of BFO layer denoted by rectangle 1 in Fig. 2a with corresponding FFT pattern as an inset ; (b) HRTEM image of STO substrate denoted by rectangle 2 in Fig. 2a with corresponding FFT patterns as an inset.)

面体晶構造に特有の NBED パターンが明暸に, かつSTO 基板の NBED パターンと重複することなく観測するこ とができており，[010 $]_{\mathrm{STO}}$ に比べて $[011]_{\mathrm{STO}}$ 方位のほう がBFOの菱面体構造の同定に優れていることが明らか となった。

\section{$3.5[13 \overline{1}]_{\text {STO }}$ 方位からの NBED や構造因子計算結果}

図 $5 a$ と図 $5 \mathrm{c} に[010]_{\mathrm{STO}}$ の断面試料を TEM 観察室の 中で $25^{\circ}$ 傾斜させて得られたBFOと STOからのNBED パターンを示す。図 $5 b$ と図 $5 d$ は各々と対応した構造 因子の計算結果である。図5aは菱面体晶構造のBFOの [441] 回折パターン, 図5cはSTOの [13ī] 回折パター ンと一致していることがわかる。 $[010]_{\mathrm{STO}}$ と $[13 \overline{1}]_{\mathrm{STO}}$ の 間の角度は $25.2^{\circ}$ である。実際に測定すると $[241]_{\mathrm{BFO}}$ と $[441]_{\mathrm{BFO}}$ の角度は $25^{\circ}$ であり計算結果と一致することが わかる。しかし， [131 $]_{\mathrm{STO}}$ 方位と $[010]_{\mathrm{STO}}$ 方位の場合，

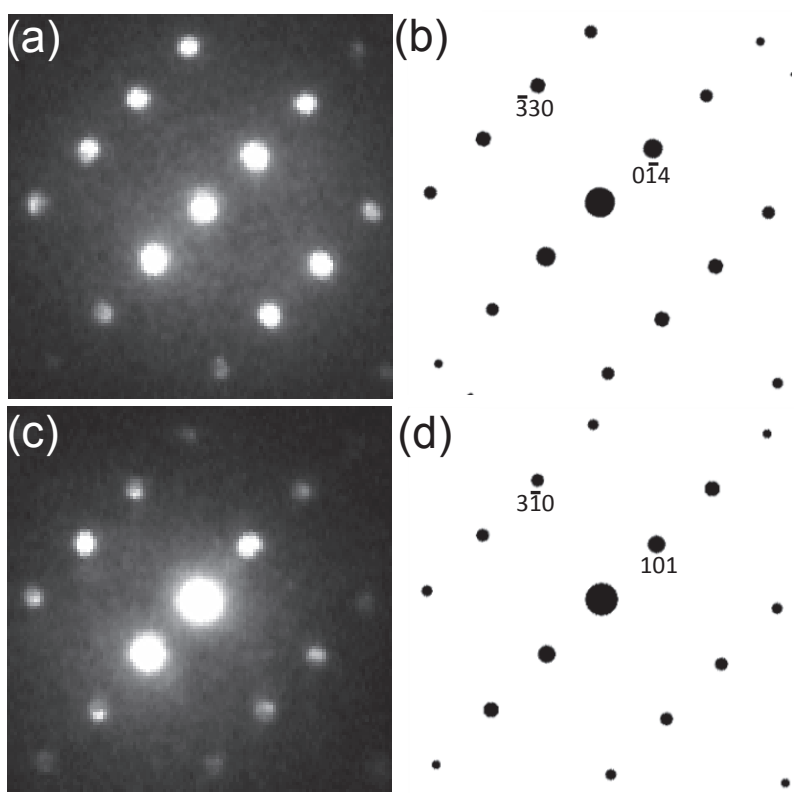

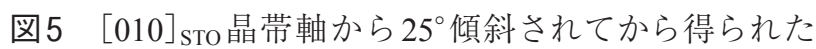
(a) BFO 薄膜と（c）STO基盤からのNBEDパター ン.(b) と（d）は各々に相当する構造因子の計 算結果である.19) (NBED patterns from BFO layer (a) and STO substrate (c) that are acquired $\sim 25^{\circ}$ away from $[010]_{\text {STO zone axis. The corresponding SF }}$ calculation is shown in (b) and (d).)

$\mathrm{STO}$ 基板とのNBEDパターンが似ているため, NBEDパ ターンの分離のために高精度の観察を行う必要がある。 このように, 3 方位で電子線回折実験を行って比較検討 したところ, $[011]_{\mathrm{STO}}$ 方位が最も明瞭に菱面体晶の構造 を判別できることが明らかとなった． 1 方位からの観測 により擬立方晶との区別を判断する場合, [011 $]_{\mathrm{STO}}$ 方位 からの断面観察が最も多くの情報を得られることがわ かった

\section{6 エピタキシャル関係とその原子モデル}

図6は [010 $]_{\mathrm{STO}}$ 方位 [図2]と [011 $]_{\mathrm{STO}}$ 方位 [図3]の構 造解析を元にして得られたエピタキシャル関係を実空間 での原子モデルで示した構造モデルである（BFOと STO の界面が直線であるのは原子モデルを簡単にして視覚的 に理解しやすくするためであり, 実際の界面の構造を正 確に反映していない). $[010]_{\mathrm{STO}}\left(=[241]_{\mathrm{BFO}}\right)$ 方位から の原子配列である図6aから, BFO と STOの面垂直や面 内方位の格子面の間隔が類似していることが直感的に理 解できる. 図6bは $[011]_{\mathrm{STO}}\left(=[211]_{\mathrm{BFO}}\right)$ 方位からの原 子配列を観察しており, 同様に面垂直や面内方位の格子 面の間隔が類似しているのがわかる。これらの結果は, $\mathrm{BFO} / \mathrm{STO}$ の界面での格子歪みが最小限となっているこ とを視覚的に導くものである. 以上のことから, BFO薄 膜はSTO基板上に成長する際，界面での格子歪みを最 小限に抑えて菱面体構造を保ちながらエピタキシャル関 係をもって成長することがわかった。 

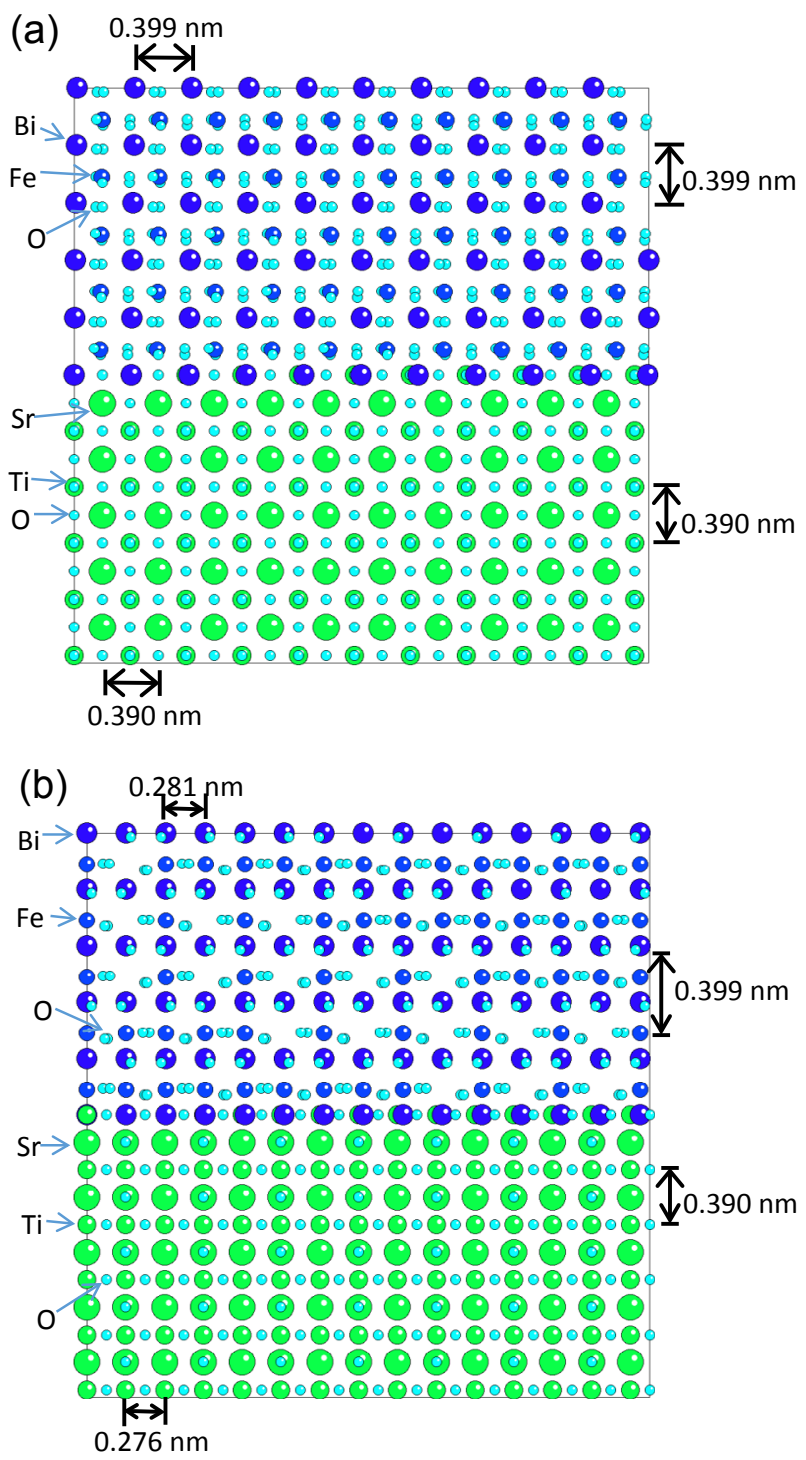

図6 $[010]_{\mathrm{STO}}\left(=[241]_{\mathrm{BFO}}\right)$ 晶帯軸 $(\mathrm{a})$ と $[011]_{\mathrm{STO}}\left(=[211]_{\mathrm{BFO}}\right)$ 晶帯軸(b) から投影された場合, BFO/STOの界面で の原子配列モデル. ${ }^{19)}$ (Atomistic models of BFO/STO interface when projected along $[010]_{\mathrm{STO}}\left(=[241]_{\mathrm{BFO}}\right)$ orientation $(\mathrm{a})$ and along $\left.[011]_{\mathrm{STO}}\left(=[211]_{\mathrm{BFO}}\right).\right)$

\section{4. おわりに}

本研究では（100）STO基板上に超高真空スッパッタ リングで成膜した膜厚 $30 \mathrm{~nm}$ の BFO エピタキシャル薄膜 の結晶構造について, 3 方位からの TEMの電子線回折扮 よび構造因子計算から包括的に調べた. 3 方位から行っ た構造解析の結果はすべて一致しており, BFO薄膜はバ ルクの結晶構造と同じ菱面体晶構造を有し, 以下のエピ タキシャル関係であることがわかった。

[241] of BFO//[010] of STO ;

$(20 \overline{4})$ of BFO// (200) of STO (along $\left.[010]_{\mathrm{sTO}}\right)$

[211] of $\mathrm{BFO} / /[011]$ of STO ;

$(10 \overline{2})$ of $\mathrm{BFO} / /(200)$ of STO (along $\left.[011]_{\mathrm{STO}}\right)$
BFOが菱面体晶構造を保って STO上に成長しているた め, その界面では格子歪みが最小限 $(<2.5 \%)$ に抑えら れるように成長していた，また，3方位の解析を比較した ところ, $[010]_{\mathrm{STO}}$ および $[13 \overline{1}]_{\mathrm{STO}}$ に比べて $[011]_{\mathrm{STO}}$ 方位 は菱面体晶構造に特有の回折パターンが明暸に分離し て現れていた。 [011 $]_{\mathrm{STO}}$ 方位からの回折パターンと構造 因子計算が $\mathrm{BFO}$ 薄膜の構造解析やその結晶成長機構を 調べるために有用であることを証明された，現在, BFO 極薄膜の構造解析, および収差補正 $\mathrm{TEM}^{27)}$ によりさらに 詳細な BFOの結晶構造と電子構造を調べる研究を行っ ている.

\section{謝 辞}

本研究の一部は, NY州立大学 Binghamton 校の Small Scale Systems Integration and Packaging center $\left(S^{3} I P\right)$ を利 用して行われた。 また, 科研費基盤 (B) (No.25600067), 科研費基盤（S）（No.24226001），NEDO若手の助成によ り行われた（HN）本論文の執筆掞よび議論は若手研究 者海外派遣プログラムの期間中に行われた。

\section{文 献}

1) G. A. Smolenskii and I. E. Chupis: Sov. Phys. Usp. 25, 475 (1982).

2) S. V. Kiselev, R. P. Ozerov and G. S. Zhdanov: Sov. Phys. Dokl. 7, 742 (1963).

3) J. R. Teague, R. Gerson and W. J. James: Sol. Stat. Comm., 8, 1073 (1970).

4) J. Wang, J. B. Neaton, H. Zheng, V. Nagarajan, S. B. Ogale, B. Liu, D. Viehland, V. Vaithyanathan, D. G. Schlom, U. V. Waghmare, N. A. Spaldin, K. M. Rabe, M. Wuttig and R. Ramesh: Science 299, 1719 (2003).

5) C. Ederer and N. A. Spaldin: Phy. Rev. Lett., 95, 257601 (2005).

6) V. Garcia, S. Fusil, K. Bouzehouane, S. E. -Vedrenne, N. D. Mathur, A. Barthélémy and M. Bibes: Nature 460, 81 (2009).

7) H. Yamada, V. Garcia, S. Fusil, S. Boyn, M. Marinova, Alexandre Gloter, S. Xavier, J. Grollier, E. Jacquet, C. Carrétéro, C. Deranlot, M. Bibes and A. Barthélémy: ACS Nano 7, 5385 (2013).

8) Y. -H. Chu, L. W. Martin, M. B. Holcomb, M. Gajek, S. -J. Han, Q. He, N. Balke, C. -H. Yang, D. Lee, W. Hu, Q. Zhan, P. -L. Yang, A. F. -Rodr'iguez, A. Scholl, S. X. Wang and R. Ramesh: Nature 7, 478 (2008).

9) K. Sone, H. Naganuma, M. Ito, T. Miyazaki, T. Nakajima and S. Okamura: Sci. Rep. 5, 09348 (2015).

10) M. K. Singh, S. Ryu and H. M. Jang: Phys. Rev. B 72, 132101 (2005).

11) J. Li, J. Wang, M. Wuttig, R. Ramesh, N. Wang, B. Ruette, A. P. Pyatakov, A. K. Zvezdin and D. Viehland: Appl. Phys. Lett. 84, 5261 (2004).

12) G. Xu, H. Hiraka, G. Shirane, J. Li, J. Wang and D. Viehland: Appl. Phys. Lett. 86, 182905 (2005)

13) G. Xu, J. Li and D. Viehland: Appl. Phys. Lett. 89, 222901 (2006).

14) H. Liu, P. Yang, K. Yao and J. Wang: Appl. Phys. Lett. 98, 102902 (2011).

15) M. Ishimaru, I. -T. Bae, Y. Hirotsu, S. Matsumura and K. E. Sickafus: Phys. Rev. Lett. 89, 055502 (2002).

16) I. -T. Bae, M. Ishimaru, Y. Hirotsu and K. E. Sickafus: J. Appl. Phys. 96, 1451 (2004). 
17) R. R. Das, D. M. Kim, S. H. Baek, C. B. Eom, F. Zavaliche, S. Y. Yang, R. Ramesh, Y. B. Chen, X. Q. Pan, X. Ke, M. S. Rzchowski and S. K. Streiffer: Appl. Phys. Lett. 88, 242904 (2006).

18) Y. B. Chen, M. B. Katz, X. Q. Pan, R. R. Das, D. M. Kim, S. H. Baek and C. B. Eom: Appl. Phys. Lett. 90, 072907 (2007).

19) In-Tae Bae and H. Naganuma: Appl. Phys. Exp. 8, 031501 (2015).

20) http://www.gatan.com/products/tem-imaging-spectroscopy/oriuscameras

21) H. Naganuma, T. Ichinose, H. A. Begum, S. Sato, X. F. Han, T. Miyazaki, In-Tae Bae, M. Oogane and Y. Ando: AIP Adv. 4, 087133 (2014).

22) D. B. Williams and C. B. Carter: Transmission Electron Microscopy (Plenum, New York, 1996), Chap. 18.

23) Y. H. Kim, A. Bhatnagar, E. Pippel, M. Alexe and D. Hesse: J. Appl. Phys. 115, 043526 (2014).

24) A. Palewicz, R. Przenioslo, I. Sosnowska and A. W. Hewat: Acta Crystallogr., Sec. B: Struct. Sci. 63, 537 (2007).

25) R. Haumont, I. A. Kornev, S. Lisenkov, L. Bellaiche, J. Kreisel and B. Dkhil: Phys. Rev. B 78, 134108 (2008).

26) D. Ricinschi, K. Y. Yun and M. Okuyama: J. Phys.: Condens. Matter 18, L97 (2006).

27) In-Tae Bae, H. Naganuma, T. Ichinose and K. Sato: Phys. Rev. B, 96, 064115 (2016).

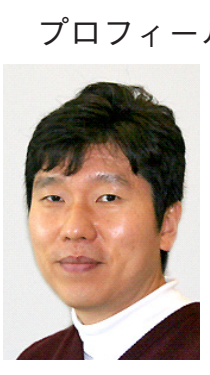

裴 寅坌 In-Tae BAE

ニューヨーク州立大学ビンハムトン

State University of New York at Binghamton

85 Murray Hill Road, Vestal, New York 13850, USA e-mail: itbae@binghamton.edu

最終学歴: 大阪大学工学研究科博士課程

専門分野：半導体薄膜結晶成長機構, 透過型電子 顕微鏡

現在の研究テーマ: マルチフェロイック薄膜に

て結晶構造と物性の相関関係

趣味：テニス, オペラ鑑賞

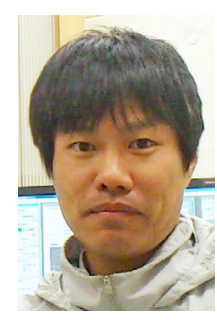

永沼 博 Hiroshi NAGANUMA

東北大学大学院工学研究科応用物理学専攻

于 980-0876 宮城県仙台市青葉区荒巻字青葉 6-6-05

Department of Applied Physics, Graduate School of Engineering, Tohoku University

6-6-05 Aoba Aramaki Aoba-ku, Sendai, Miyagi, 9808579 Japan

UMP CNRS/Thales, パリ南大学

CNRS/Thales, Univ. Paris-Sud, Universite ParisSaclay, 91767 Palaiseau, France

e-mail: naganumahiroshi1@gmail.com

最終学歷: 大阪大学大学院博士課程

専門分野：マルチフェロイックス, スピントロニ クス

現在の研究テーマ: 二次元電子ガスのスピン電導

趣味：ホード, バイクなど 